\title{
APPLICATION OF LEAN PRINCIPLES IN THE SOUTH AFRICAN CONSTRUCTION INDUSTRY
}

\author{
I. Maradzano ${ }^{1 \#}$, R.A. Dondofema ${ }^{1} \&$ S. Matope ${ }^{1 *}$
}

\section{ARTICLE INFO}

\section{Article details}

Presented at the $30^{\text {th }}$ annual conference of the Southern African Institute for Industrial Engineering (SAIIE), held from 30 September - 2 October 2019 in Port Elizabeth, South Africa

Available online

15 Nov 2019

\section{Contact details}

Corresponding author

smatope@sun.ac.za

\section{Author affiliations}

1 Department of Industrial Engineering, University of Stellenbosch, South Africa

\# The author was enrolled for an M Eng. (Research) Industrial Engineering degree in the Department of Industrial Engineering, Stellenbosch University, South Africa

DOI

http://dx.doi.org/10.7166/30-3-2240
ABSTRACT

South Africa is a developing country that invests billions of rands annually in the construction industry. This industry consumes resources and, inevitably, waste is generated during the process. Although numerous approaches have been developed to improve quality, efficiency, and effectiveness in this industry, lean principles offer the ability to minimise and/or eliminate non-value adding work, thus increasing value for the client. This paper highlights the lean construction tools currently used worldwide, and the benefits of adopting lean construction. The study surveyed publications on the application of lean principles in the construction industry, and identified tools yet to be implemented in the South African construction industry with specific reference to electrical and mechanical engineering services. The study used a systematic review methodology to identify different lean construction concepts, and developed a lean implementation framework. The framework was then evaluated using a local case focusing on electrical and mechanical engineering services in the construction industry. The improved framework after evaluation consists of eight steps.

\section{OPSOMMING}

Suid-Afrika is ' $n$ ontwikkelende land wat miljarde rande jaarliks in die konstruksiebedryf belê. Hierdie industrie verbruik hulpbronne en genereer afval tydens die proses. Alhoewel vele benaderings reeds ontwikkel is om die gehalte, effektiwiteit en doeltreffendheid in hierdie industrie te verbeter, bied lenige beginsels die vermoë om take wat nie waarde toevoeg nie te minimeer en/of te elimineer. Hierdie artikel beklemtoon die lenige konstruksietegnieke wat wêreldwyd gebruik word saam met die voortspruitende voordele. Publikasies rakende die toepassing van lenige beginsels in die konstruksiebedryf is nagevors en tegnieke (gespits op elektriese en meganiese ingenieursdienste) wat nog nie in die Suid-Afrikaanse bedryf toegepas is nie, is identifiseer. Hierdie studie het 'n sistematiese hersieningsmetodologie gebruik om die verskillende lenige konsepte te identifiseer en het daarmee saam ' $n$ lenige implementeringsraamwerk ontwikkel. Hierdie raamwerk is evalueer aan die hand van 'n plaaslike gevallestudie. Die verbeterde raamwerk bestaan uit agt stappe.

\section{INTRODUCTION}

Lean manufacturing methodology helps to identify and eliminate or reduce waste in any production process. Waste can be defined as any non-value adding activity in any production process [26] [44]. These non-value adding activities do not improve value; they only increase cost and overall production time [40]. However, non-value adding activities should be distinguished from essential non-value adding activities and non-essential value adding activities [51]. By planning adequately, with proper supervision and correct decision-making based on accurate information and procedures, lean manufacturing principles, if implemented in the South African construction industry, have the 
potential to eliminate waste, which takes place through the removal of non-essential value adding activities; this leads to cost reduction and performance improvement [7]. Eventually this will improve the overall construction time and deliver quality projects timeously [61].

The construction industry has been lagging (compared with the manufacturing industry) in implementing and improving lean principles and methodologies [6]. This criticism has stimulated research on the application of lean manufacturing principles in the construction sector - hence the coining of the term 'lean construction' [52]. Lean construction's roots can be dated back to the late 1990s [48]. Koskela and Howell [48] proposed analyzing construction activities using production engineering analytical tools. Efforts were made to improve productivity and increase competitiveness in the construction industry. Currently, construction industry participants are exploring new techniques, practices, and processes to make the industry less wasteful [12]. Lean principles, when applied in the construction industry (which will be referred to as 'lean construction' in this paper), offer innovative ways to manage construction projects while reducing waste and improving quality, efficiency, and performance.

The South African construction industry contributes to a large extent to the economy of the country, particularly in setting up physical infrastructure [63]. On the other hand, while most of the activities of this industry have negative effects on the environment, these can be improved through changes in the management of waste [28]. The lean construction philosophy originated from the lean manufacturing concept - mainly from the Toyota production system [74] [70] [18]. The successful implementation of lean principles in the manufacturing industry, and the benefits resulting from their adoption, is one of the key reasons for the adoption of lean thinking in construction [33]. The term 'lean construction' was introduced by the International Group for Lean Construction at the first conference on lean construction in Finland in 1993 [8]. According to Koskela, Huovila and Leinonen [49], lean construction is "a way to design production systems to minimize waste of materials, time and effort to generate the maximum possible amount of value". Implementation of lean construction principles is paramount in decreasing waste and enhancing the South African construction industry's overall performance.

\subsection{Review of lean techniques}

Many projects in South Africa experience time delays and cost overruns and generate substantial amounts of waste. Lean construction has been introduced to address these challenges in the South African construction industry; however, it is still in its infancy. The construction industry is also characterised by poor quality work, poor safety, and negative effects on the environment [18]. From the available literature on lean construction implementation, the appropriateness of lean construction practices in the construction industry remains a subject of substantial discussion [62] [71] [69]. Table 1 summarises nineteen lean tools that are currently being implemented worldwide in lean construction, as identified in the literature. From these nineteen lean tools, only four have been found in the literature as being used in the South African construction industry. Higher level techniques such as Kanban and 'just in time' (JIT) are yet to be fully applied.

From the analysis in Table 1, the authors observed that the lean tools used in the construction industry are the Kanban system, value stream mapping, first run studies (plan-do-check-act), total quality management, poka-yoke, failure mode and effect analysis, 5 whys, JIT, increased visualisation, standardisation, last planner system, waste elimination, and continuous improvement. According to Salem, Solomon, Genaidy \& Minkarah [69], three characteristics differentiate the construction industry from the manufacturing industry: 1) unique projects, 2) complexity, and 3 ) on-site production. These key differences make it difficult simply to transfer the lean tools in Table 1 from the manufacturing industry to the construction industry. 
Table 1: Lean tools currently used worldwide to support lean construction implementation

\begin{tabular}{|c|c|c|}
\hline Lean tool & Definition & $\begin{array}{l}\text { Is the lean tool being } \\
\text { applied in the South } \\
\text { African industry? }\end{array}$ \\
\hline JIT & $\begin{array}{l}\text { The JIT method is a supply management tool driven by the } \\
\text { customer's demand. Its aim is to maintain a construction } \\
\text { material flow that matches the internal/external customer } \\
\text { requirements to optimise inventory and work-in-progress } \\
\text { [18] [23] [64]. }\end{array}$ & $\begin{array}{l}\text { In the collected } \\
\text { literature, the } \\
\text { authors did not find } \\
\text { any evidence of the } \\
\text { application of this } \\
\text { tool. }\end{array}$ \\
\hline The 5s process & $\begin{array}{l}\text { This is a systematic housekeeping process that is performed } \\
\text { in its five distinctive steps: sorting, straightening, shining, } \\
\text { standardising, and sustaining the facilities and processes } \\
\text { used in construction. The } 5 \text { s process increases the } \\
\text { productivity of the project, as it reduces the time spent } \\
\text { searching for supplies, tools, equipment, etc. [11] [27] } \\
\text { [72]. }\end{array}$ & $\begin{array}{l}\text { In the collected } \\
\text { literature, the } \\
\text { authors did not find } \\
\text { any evidence of the } \\
\text { application of this } \\
\text { tool. }\end{array}$ \\
\hline 5 whys & $\begin{array}{l}\text { This is a problem-solving technique used to identify the } \\
\text { root causes of a targeted problem. It is a question-asking } \\
\text { technique that illuminates cause-and-effect mechanisms } \\
\text { associated with a problem [19] [16] [34] [70]. }\end{array}$ & $\begin{array}{l}\text { Yes, this tool is } \\
\text { currently used in the } \\
\text { South African } \\
\text { construction industry. } \\
\text { [80] }\end{array}$ \\
\hline Standardisation & $\begin{array}{l}\text { Standardisation can be described as a set of methods, } \\
\text { components, or processes in which there is repetition and } \\
\text { regularity leading to successful practices - also called } \\
\text { 'standard operating procedures' (SOP). This technique } \\
\text { allows building in the shortest possible time and with the } \\
\text { minimum of effort [38] [64] [45]. }\end{array}$ & $\begin{array}{l}\text { In the collected } \\
\text { literature, the } \\
\text { authors did not find } \\
\text { any evidence of the } \\
\text { application of this } \\
\text { tool. }\end{array}$ \\
\hline Prefabrication & $\begin{array}{l}\text { This consists of using modularised and prefabricated } \\
\text { construction components, and aims to overcome the } \\
\text { common production problems encountered during on-site } \\
\text { construction (i.e., low output quality, low productivity, } \\
\text { high variability, and poor safety) [65] [19] [58]. }\end{array}$ & $\begin{array}{l}\text { In the collected } \\
\text { literature, the } \\
\text { authors did not find } \\
\text { any evidence of the } \\
\text { application of this } \\
\text { tool. }\end{array}$ \\
\hline $\begin{array}{l}\text { The last planner } \\
\text { system (LPS) }\end{array}$ & $\begin{array}{l}\text { This achieves the lean goals of reducing waste, increasing } \\
\text { productivity, and decreasing unpredictability, mainly } \\
\text { through a social process, by trying to make planning a } \\
\text { mutual attempt and by increasing the reliability of the } \\
\text { commitment of team members. In construction, LPS is a } \\
\text { method that forms workflow and deals with project } \\
\text { variability [50] [73] [22] [68]. }\end{array}$ & $\begin{array}{l}\text { In the collected } \\
\text { literature, the } \\
\text { authors did not find } \\
\text { any evidence of the } \\
\text { application of this } \\
\text { tool. }\end{array}$ \\
\hline $\begin{array}{l}\text { Value stream } \\
\text { mapping (VSM) }\end{array}$ & $\begin{array}{l}\text { An information and material flow mapping tool that is used } \\
\text { to graphically visualise the current value stream and design } \\
\text { the future state of the construction process while reducing } \\
\text { all sources of waste (overproduction, waiting, inventory, } \\
\text { displacements, etc.) [14] [20] [75]. }\end{array}$ & $\begin{array}{l}\text { In the collected } \\
\text { literature, the } \\
\text { authors did not find } \\
\text { any evidence of the } \\
\text { application of this } \\
\text { tool. }\end{array}$ \\
\hline $\begin{array}{l}\text { Continuous } \\
\text { improvement } \\
\text { (kaizen) }\end{array}$ & $\begin{array}{l}\text { This technique supports the idea that every process can, } \\
\text { and should, be continually measured, analysed, and } \\
\text { improved in terms of resources used, time required, quality } \\
\text { demanded by customers, and other performance criteria } \\
\text { relevant to the construction [70] [27]. }\end{array}$ & $\begin{array}{l}\text { Yes, this tool is } \\
\text { currently used in the } \\
\text { South African } \\
\text { construction industry. } \\
\text { [7] [77] }\end{array}$ \\
\hline $\begin{array}{l}\text { Total productive } \\
\text { maintenance (TPM) }\end{array}$ & $\begin{array}{l}\text { This tool is an integrated approach to maintenance that } \\
\text { focuses on proactive and preventative maintenance to } \\
\text { maximise the operational time of equipment. TPM blurs the } \\
\text { distinction between maintenance and production by placing } \\
\text { a strong emphasis on empowering operators to help } \\
\text { maintain their equipment [9] [23]. }\end{array}$ & $\begin{array}{l}\text { In the collected } \\
\text { literature, the } \\
\text { authors did not find } \\
\text { any evidence of the } \\
\text { application of this } \\
\text { tool. }\end{array}$ \\
\hline $\begin{array}{l}\text { Total quality } \\
\text { management (TQM) }\end{array}$ & $\begin{array}{l}\text { Most of the substantial tools used to address construction } \\
\text { performance issues are based on the concept of plan-do- } \\
\text { act. Functions involve the identification and evaluation of } \\
\text { the problem, developing and implementing solutions, and } \\
\text { evaluating and measuring the results [46] [55]. }\end{array}$ & $\begin{array}{l}\text { In the collected } \\
\text { literature, the } \\
\text { authors did not find } \\
\text { any evidence of the } \\
\text { application of this } \\
\text { tool. }\end{array}$ \\
\hline Pareto analysis & $\begin{array}{l}\text { The Pareto chart is a graph highlighting the most important } \\
\text { causes that have an effect on the analysed system; it thus }\end{array}$ & $\begin{array}{l}\text { In the collected } \\
\text { literature, the } \\
\text { authors did not find }\end{array}$ \\
\hline
\end{tabular}




\begin{tabular}{|c|c|c|}
\hline Lean tool & Definition & $\begin{array}{l}\text { Is the lean tool being } \\
\text { applied in the South } \\
\text { African industry? }\end{array}$ \\
\hline & $\begin{array}{l}\text { allows the development of innovative actions to improve } \\
\text { the current situation [15] [53]. }\end{array}$ & $\begin{array}{l}\text { any evidence of the } \\
\text { application of this } \\
\text { tool. }\end{array}$ \\
\hline Ishikawa diagram & $\begin{array}{l}\text { This effective quality tool is used to identify the causes of } \\
\text { an inherent problem. The Ishikawa diagram is considered a } \\
\text { powerful tool for the root cause analysis (RCA) approach } \\
{[31][18][60] \text {. }}\end{array}$ & $\begin{array}{l}\text { In the collected } \\
\text { literature, the } \\
\text { authors did not find } \\
\text { any evidence of the } \\
\text { application of this } \\
\text { tool. }\end{array}$ \\
\hline Waste elimination & $\begin{array}{l}\text { This technique is the core of the lean construction concept. } \\
\text { It aims at spreading a culture among employees to } \\
\text { eliminate the various sources of waste (overproduction, } \\
\text { quality defects, unnecessary transportation, over- } \\
\text { processing, waiting, inventory, displacements, and unused } \\
\text { employee creativity) [43] [47] [76]. }\end{array}$ & $\begin{array}{l}\text { Yes, this tool is } \\
\text { currently used in the } \\
\text { South African } \\
\text { construction industry. } \\
\text { [78] [81] }\end{array}$ \\
\hline $\begin{array}{l}\text { Daily huddle } \\
\text { meetings }\end{array}$ & $\begin{array}{l}\text { These are held to obtain the full involvement of employees } \\
\text { in issues regarding the project, and to encourage } \\
\text { employees to solve problems together. Two-way } \\
\text { communication is the key to the daily huddle meeting } \\
\text { process to achieve employee involvement [4] [16] [60] [68]. }\end{array}$ & $\begin{array}{l}\text { In the collected } \\
\text { literature, the } \\
\text { authors did not find } \\
\text { any evidence of the } \\
\text { application of this } \\
\text { tool. }\end{array}$ \\
\hline $\begin{array}{l}\text { Plan of conditions } \\
\text { and work } \\
\text { environment in the } \\
\text { construction } \\
\text { industry }\end{array}$ & $\begin{array}{l}\text { This is a lean construction tool that assures occupational } \\
\text { safety and health management. It manages safety } \\
\text { requirements through the risk management cycle, } \\
\text { consisting of continuous identification of risk, evaluation, } \\
\text { and control [16] [60]. }\end{array}$ & $\begin{array}{l}\text { In the collected } \\
\text { literature, the } \\
\text { authors did not find } \\
\text { any evidence of the } \\
\text { application of this } \\
\text { tool. }\end{array}$ \\
\hline $\begin{array}{l}\text { Pull ‘kanban' } \\
\text { system }\end{array}$ & $\begin{array}{l}\text { Pull systems are a lean approach developed in the } \\
\text { automotive industry as a mechanism to pull materials and } \\
\text { parts throughout the value stream on a JIT basis. } \\
\text { Japanese word 'kanban' means 'card' or 'sign', and is the } \\
\text { name given to the inventory control card used in a pull } \\
\text { system [13] [37] [24]. }\end{array}$ & $\begin{array}{l}\text { In the collected } \\
\text { literature, the } \\
\text { authors did not find } \\
\text { any evidence of the } \\
\text { application of this } \\
\text { tool. }\end{array}$ \\
\hline $\begin{array}{l}\text { Error proofing } \\
\text { (poka-yoke) }\end{array}$ & $\begin{array}{l}\text { Poka-yoke, a Japanese word, is a mechatronic device that } \\
\text { works as error proofing, avoiding mistakes and preventing } \\
\text { defects from flowing through the process. It increases the } \\
\text { quality of the construction process and improves conditions } \\
\text { of safety for the workers [2] [11] [20] [30]. }\end{array}$ & $\begin{array}{l}\text { In the collected } \\
\text { literature, the } \\
\text { authors did not find } \\
\text { any evidence of the } \\
\text { application of this } \\
\text { tool. }\end{array}$ \\
\hline $\begin{array}{l}\text { Target value design } \\
\text { (TVD) }\end{array}$ & $\begin{array}{l}\text { This approach applies methods for the design to be } \\
\text { developed in accordance with the constraints, especially } \\
\text { cost (i.e., 'design-to-cost' or 'design-to-targets'). TVD } \\
\text { considers the customer's vision to define restrictions and } \\
\text { deliver the required target values [56]. }\end{array}$ & $\begin{array}{l}\text { In the collected } \\
\text { literature, the } \\
\text { authors did not find } \\
\text { any evidence of the } \\
\text { application of this } \\
\text { tool. }\end{array}$ \\
\hline $\begin{array}{l}\text { Failure mode, } \\
\text { effects and } \\
\text { criticality analysis } \\
\text { (FMECA) }\end{array}$ & $\begin{array}{l}\text { Risk analysis is an essential step in construction project } \\
\text { management. It is a method of qualitative analysis of } \\
\text { reliability, which makes it possible to assess the risks of the } \\
\text { appearance of failures, to evaluate their consequences, } \\
\text { and to identify their root causes [11] [37]. }\end{array}$ & $\begin{array}{l}\text { Yes, this tool is } \\
\text { currently used in the } \\
\text { South African } \\
\text { construction industry. } \\
\text { [77] [78] }\end{array}$ \\
\hline
\end{tabular}

\subsection{Benefits of lean construction}

Lean construction has made significant improvements in terms of the timely completion of construction projects [5]. These improvements are facilitated by the way the construction site is managed and controlled, and are shown in Table 2 [1] [3] [7] [14] [29] [36] [41] [42] [45] [50] [52] [57] [58] [59] [69] [80] [81]. Applications of lean principles in construction have resulted in efficiency improvement of overall equipment effectiveness (OEE), as seen from Table 2. The main benefits of lean construction are reduction of waste, customer satisfaction, and overall project cost reduction. Lean construction helps construction companies to identify and analyse waste to improve productivity, reduce project duration, improve safety, improve quality, ensure customer satisfaction, and improve reliability. 
Table 2: Lean construction benefits

\begin{tabular}{|c|c|c|}
\hline Benefits & Project type & $\begin{array}{l}\text { Has the South African industry benefitted } \\
\text { from this benefit? }\end{array}$ \\
\hline Reducing total project duration & $\begin{array}{l}\text { Industrial projects } \\
\text { Residential building } \\
\text { projects } \\
\text { Housing estate } \\
\text { projects/units }\end{array}$ & $\begin{array}{l}\text { According to Akinradewo, Oke, Aigbavboa \& } \\
\text { Ndalamba [7], the South African construction } \\
\text { industry benefits from this. }\end{array}$ \\
\hline $\begin{array}{l}\text { Quick turnover and low cost of } \\
\text { construction projects }\end{array}$ & $\begin{array}{l}\text { Construction \& civil } \\
\text { engineering } \\
\text { infrastructure projects }\end{array}$ & $\begin{array}{l}\text { In the collected literature, the authors did } \\
\text { not find any evidence of this benefit. }\end{array}$ \\
\hline Improving quality of work & $\begin{array}{l}\text { Infrastructure projects } \\
\text { Commercial buildings }\end{array}$ & $\begin{array}{l}\text { In the collected literature, the authors did } \\
\text { not find any evidence of this benefit. }\end{array}$ \\
\hline $\begin{array}{l}\text { Improving environmental } \\
\text { performance }\end{array}$ & $\begin{array}{l}\text { Housing estate } \\
\text { projects } \\
\text { Residential, } \\
\text { institutional, and } \\
\text { commercial }\end{array}$ & $\begin{array}{l}\text { In the collected literature, the authors did } \\
\text { not find any evidence of this benefit. }\end{array}$ \\
\hline Improving the safety of workers & $\begin{array}{l}\text { Residential, } \\
\text { institutional, and } \\
\text { commercial }\end{array}$ & $\begin{array}{l}\text { According to Akinradewo et al. [7] and Emuze } \\
\text { \& Ungerer [80], the South African } \\
\text { construction industry benefits from this. }\end{array}$ \\
\hline $\begin{array}{l}\text { Improved project delivery } \\
\text { methods }\end{array}$ & $\begin{array}{l}\text { Construction \& civil } \\
\text { engineering }\end{array}$ & $\begin{array}{l}\text { In the collected literature, the authors did } \\
\text { not find any evidence of this benefit. }\end{array}$ \\
\hline Managing uncertainties in supply & $\begin{array}{l}\text { Hospital construction } \\
\text { Housing estate } \\
\text { projects }\end{array}$ & $\begin{array}{l}\text { In the collected literature, the authors did } \\
\text { not find any evidence of this benefit. }\end{array}$ \\
\hline $\begin{array}{l}\text { Supporting the development of } \\
\text { team work, and transferring the } \\
\text { responsibility in the supply chain }\end{array}$ & Renovation projects & $\begin{array}{l}\text { In the collected literature, the authors did } \\
\text { not find any evidence of this benefit. }\end{array}$ \\
\hline $\begin{array}{l}\text { Continuous improvement in } \\
\text { projects }\end{array}$ & $\begin{array}{l}\text { Residential building } \\
\text { projects }\end{array}$ & $\begin{array}{l}\text { According to Monyane, Awuzie \& Emuze [81], } \\
\text { lean construction implementation enhances } \\
\text { continuous improvement within projects. }\end{array}$ \\
\hline $\begin{array}{l}\text { Minimisation of conflicts that can } \\
\text { dramatically change budget and } \\
\text { schedule }\end{array}$ & Infrastructure projects & $\begin{array}{l}\text { In the collected literature, the authors did } \\
\text { not find any evidence of this benefit. }\end{array}$ \\
\hline $\begin{array}{l}\text { Delivery of custom products } \\
\text { instantly without waste }\end{array}$ & $\begin{array}{l}\text { Residential, } \\
\text { institutional and } \\
\text { commercial }\end{array}$ & $\begin{array}{l}\text { In the collected literature, the authors did } \\
\text { not find any evidence of this benefit. }\end{array}$ \\
\hline $\begin{array}{l}\text { Delivery of products and services } \\
\text { on time and within budget }\end{array}$ & $\begin{array}{l}\text { Residential, } \\
\text { institutional and } \\
\text { commercial }\end{array}$ & $\begin{array}{l}\text { In the collected literature, the authors did } \\
\text { not find any evidence of this benefit. }\end{array}$ \\
\hline $\begin{array}{l}\text { Reduction of direct cost and } \\
\text { time in transportation and } \\
\text { communication }\end{array}$ & $\begin{array}{l}\text { Residential building } \\
\text { projects }\end{array}$ & $\begin{array}{l}\text { In the collected literature, the authors did } \\
\text { not find any evidence of this benefit. }\end{array}$ \\
\hline Reduced waste & $\begin{array}{l}\text { Road construction } \\
\text { projects }\end{array}$ & $\begin{array}{l}\text { According to Akinradewo et al. [7] and } \\
\text { Monyane et al. [81], lean construction } \\
\text { implementation in South Africa reduces } \\
\text { waste and increases productivity. }\end{array}$ \\
\hline $\begin{array}{l}\text { Improved overall equipment } \\
\text { effectiveness (OEE) }\end{array}$ & $\begin{array}{l}\text { Residential, } \\
\text { institutional, and } \\
\text { commercial }\end{array}$ & $\begin{array}{l}\text { In the collected literature, the authors did } \\
\text { not find any evidence of this benefit. }\end{array}$ \\
\hline $\begin{array}{l}\text { Improved quality control and } \\
\text { minimisation of risks }\end{array}$ & Infrastructure projects & $\begin{array}{l}\text { In the collected literature, the authors did } \\
\text { not find any evidence of this benefit. }\end{array}$ \\
\hline $\begin{array}{l}\text { Improved employee satisfaction } \\
\text { and supplier relationships }\end{array}$ & $\begin{array}{l}\text { Residential building } \\
\text { projects }\end{array}$ & $\begin{array}{l}\text { Yes, lean construction enhances motivation } \\
\text { [80]. }\end{array}$ \\
\hline
\end{tabular}

\subsection{Gap analysis}

From the brief analysis of the literature on lean construction, it has been observed that there are limited frameworks for the implementation of lean construction for different construction projects in the South African construction industry. The authors observed that there is limited application of lean construction in the electrical and mechanical services (wet, fire, and heating, ventilation and air conditioning (HVAC) projects), which are also key components of the construction industry. Hence the aim of this study is to develop a lean construction implementation framework that can be used to implement lean principles in mechanical and electrical services projects. 
The research design employed for this study was a systematic literature review of published literature. A systematic literature review is an important scientific research approach that can be used to appraise, summarise, and communicate the findings and implications of a large number of research publications on a particular subject [39]. Second, evidence in the literature shows that previous authors [32] [35] [54] [67] have adopted a similar approach with their respective studies. A systematic literature review is used to gather and study a huge number of research studies and publications relating to a specific subject to answer predefined questions, by incorporating the practical evidence from all relevant studies [25].

A systematic literature review is a part of research in its own right and, by its nature, is able to address much wider questions than single empirical studies ever can. Without doubt, a systematic review is at the top of the 'hierarchy of evidence' compared with other research designs, because it has the potential to deliver the most important practical implications [25]. Thus the systematic literature review focused on reviewing available studies in the construction industry through different search engines. The study was conducted in six steps, as shown in Table 3.

Table 3: Research methodology steps

\begin{tabular}{|l|l|l|}
\hline Steps & Reason for that step & $\begin{array}{l}\text { Where it is } \\
\text { presented }\end{array}$ \\
\hline $\begin{array}{l}\text { 1. Developing search } \\
\text { terms }\end{array}$ & $\begin{array}{l}\text { To develop appropriate terms that will assist to identify } \\
\text { relevant literature for the study. }\end{array}$ & Section 3.1 \\
\hline $\begin{array}{l}\text { 2. Identifying data } \\
\text { sources }\end{array}$ & $\begin{array}{l}\text { To identify the appropriate search engines; this study used } \\
\text { Web of Science, Google Scholar, and Science Direct. }\end{array}$ & Section 3.1 \\
\hline $\begin{array}{l}\text { 3. Selecting relevant } \\
\text { publications }\end{array}$ & $\begin{array}{l}\text { The papers were screened to see whether they were } \\
\text { relevant to the objective of the study. }\end{array}$ & Section 3.2 \\
\hline $\begin{array}{l}\text { 4. Analysing the } \\
\text { studies }\end{array}$ & $\begin{array}{l}\text { This step was important, as it helped to understand the } \\
\text { lean construction concepts in the literature. }\end{array}$ & $\begin{array}{l}\text { Section } 4.1 \text { \& } \\
\text { Section } 4.2\end{array}$ \\
\hline $\begin{array}{l}\text { 5. Developing a } \\
\text { framework }\end{array}$ & $\begin{array}{l}\text { To develop a framework in the context of the South } \\
\text { African mechanical and electrical services industries. }\end{array}$ & Section 5 \\
\hline $\begin{array}{l}\text {. Evaluating the } \\
\text { framework }\end{array}$ & $\begin{array}{l}\text { To evaluate the framework in the context of the South } \\
\text { African mechanical and electrical services industries. }\end{array}$ & Section 6 \\
\hline
\end{tabular}

\section{CONDUCTING THE REVIEW}

\subsection{Data sources and data collection}

To identify studies on lean construction, the authors used 'lean in construction industry' and 'lean construction' as search terms as shown in Table 4. The search fields used were article title, abstract, and keywords. The search engines used were Web of Science, Google Scholar, and Science Direct. The initial search yield is displayed in Table 4.

Table 4: Initial Search Results

\begin{tabular}{|l|l|l|l|l|}
\hline Search terms & Search field & $\begin{array}{l}\text { Web of } \\
\text { Science }\end{array}$ & $\begin{array}{l}\text { Google } \\
\text { Scholar }\end{array}$ & $\begin{array}{l}\text { Science } \\
\text { Direct }\end{array}$ \\
\hline $\begin{array}{l}\text { Lean in construction industry and } \\
\text { lean construction }\end{array}$ & $\begin{array}{l}\text { Article title, abstract, } \\
\text { and keywords }\end{array}$ & 312 & 134 & 90 \\
\hline
\end{tabular}

\subsection{Selection criteria}

Out of 536 publications found on the primary search, an extensive review was done to establish whether each publication was fit for the systematic literature review. The first screening criterion was to check whether or not the publication was related to the topic of lean construction implementation. The second vetting process was to check whether or not the publication was relevant to the scope of the study. A total of 343 publications were found to be unrelated to the topic of study. Of the 193 publications that were related to the topic, only 33 papers were relevant to the current study. Of the 33 papers found, only nine papers focused on lean construction in the South African construction industry. Figure 1 shows the document selection. 
Final data that was reviewed

Relevant for the Study

Topic Related

Intial Search yield

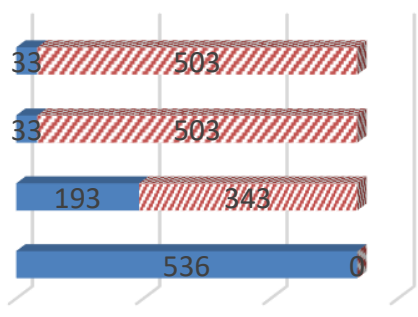

0

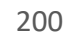

400

600

Papers remaining $\mathbb{N}$ Discarded papers

Figure 1: Document selection (see online version for colour)

\section{OUTCOMES OF THE SYSTEMATIC REVIEW}

This section is divided into two sub-sections: descriptive statistics and conceptual aspects.

\subsection{Descriptive statistics}

From the systematic literature review, it was found that documents that related to lean construction were in the form of journal articles, conference papers, industry research reports, and book chapters. The review focused on lean implementation in the construction industry, the authors selected material with a rich content of empirical data on lean construction implementation. A total of 33 publications were relevant to the current study of lean construction implementation. These were published from 2012 to 2019. Of these publications, 58 per cent were journal articles, 39 per cent conference papers, and three per cent book chapters, as shown in Figure 2. From these papers, the next step was to read the whole paper to understand the study objective, the research approach used, key concepts, and the lean tools used in each paper.

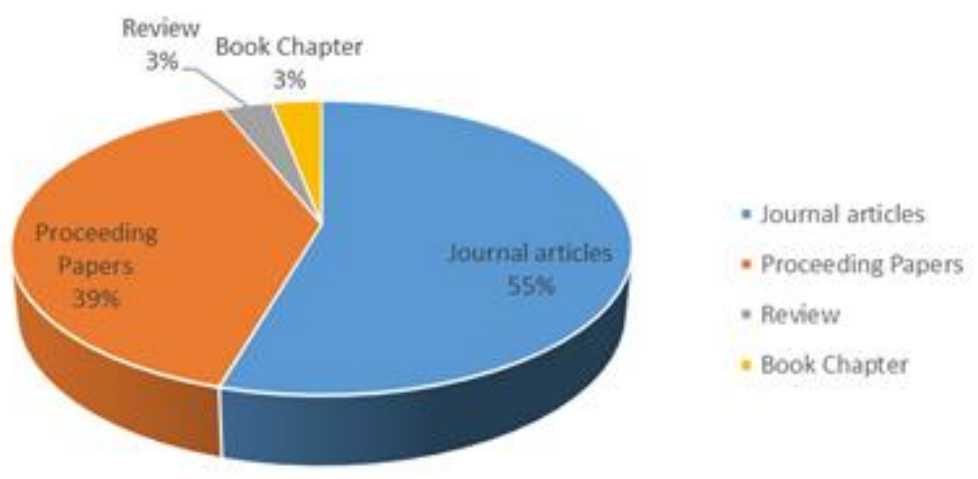

Figure 2: Paper types (see online version for colour)

Out of the 33 papers that were relevant to the current study, only nine focused on the South African construction industry. Figure 3 shows the sub-sectors in which lean construction has been applied in the South African construction industry. From these results it is evident that there is limited application of lean construction, particularly in the electrical and mechanical services (wet, fire, and heating, ventilation and air conditioning (HVAC)) in the South African construction industry. Construction and civil engineering projects involve the management of infrastructure such as roads, tunnels, bridges, airports, railroads, dams, and sewerage. Commercial buildings are those construction projects that involve building projects that can be leased or sold in the private sector. These spaces can be anything from offices and retail shopping centres to medical centres. 


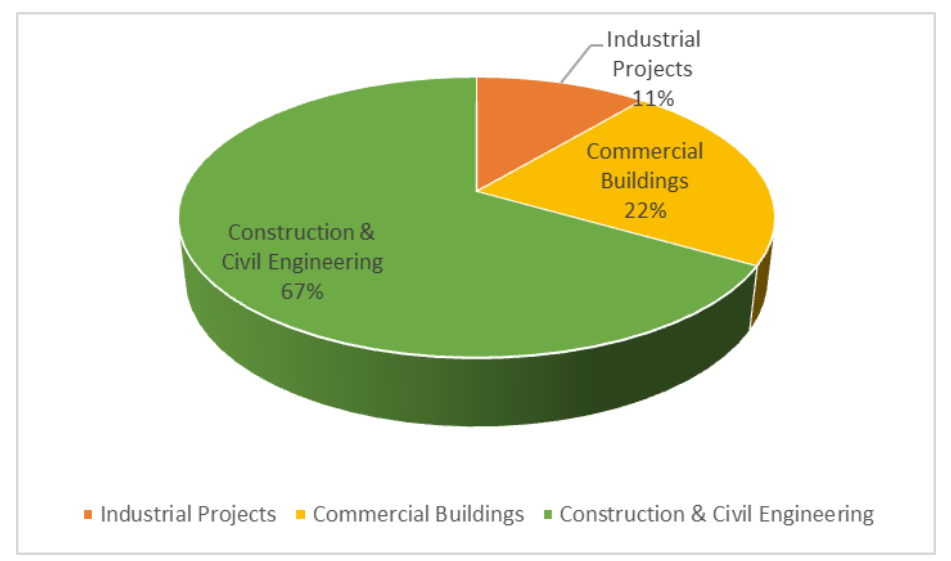

Figure 3: Project types (see online version for colour)

\subsection{Conceptual aspects}

Different concepts were identified from the systematic literature review, and were grouped into four categories, as shown in Table 5. Category 1 consists of the following concepts: understanding customer needs, identifying the value stream, and identifying value-adding and non-value-adding activities [7] [10] [21]. Category 2 focuses on investigating the current state of lean construction, identifying lean construction barriers, identifying lean construction implementation drivers, and implementing lean construction tools [2] [3] [62]. Lean implementing barriers include cultural barriers, resistance to change, and lack of knowledge about the lean construction philosophy. Category 3 highlights managerial support for the successful implementation of lean construction, government support, mind-set change, and change management of organisational culture and perception [15] [16] [17]. When the paradigm shifts, everything changes [54]. Training programmes should be made available to workforces at different levels to spread the required skills and techniques for minimising waste, such as cost and time control, scheduling, and risk analysis [54] [58] [72]. Category 4 consists of performance management, lean construction plan, lean project delivery system, project planning, and continuous improvement. There are nine lean construction key performance indicators. These are time, costs, quality, client satisfaction, environmental impact, waste, speed, value, and health and safety [36] [40] [75].

\section{Table 5: Concepts identified}

\begin{tabular}{|l|l|}
\hline Category $\mathbf{1}$ & Category $\mathbf{2}$ \\
Understand customer needs & Investigate current state of lean construction or other \\
Identify value stream & waste reduction processes \\
Identify value-adding processes & Identify lean construction barriers \\
Identify non-value-adding processes & Identify lean implementation drivers \\
Identify waste and sources of waste & Implement lean construction tools \\
\hline $\begin{array}{l}\text { Category } \mathbf{3} \\
\text { Managerial support for successful }\end{array}$ Category $\mathbf{4}$ \\
$\begin{array}{l}\text { Minplementation } \\
\text { Change management of organisation culture } \\
\text { and preparation }\end{array}$ & Performance management \\
\hline
\end{tabular}

\section{DEVELOPING THE FRAMEWORK}

From the systematic literature review, the authors developed a framework that can be used in the mechanical and electrical services industries. Lean construction focuses on getting things right, in the right place, at the desired time, and in the desired quantity [23] [32]. The framework consists of seven steps, as shown in Figure 6. The first step is to identify waste practices on site. This will enable the person tasked to implement lean construction to determine the level of comprehension of construction waste among the contractors involved in the project. The second step, as shown in Table 6, is to educate project managers and team leaders about lean construction and its benefits. This step is crucial to get support from all teams involved in the project. The third step is to identify value from the customer's perspective. The fourth stage is to identify the value stream; this is made out of all the activities that create customer value and satisfy the demands and expectations of the 
customer. In this stage, value-adding activities should be distinguished from non-value-adding activities. This will lead to the discovery of the sources of waste. The fifth step is to establish flow by minimising waste - unnecessary waiting time, storage of material, unnecessary processes, unnecessary transportation of material, movement of labour workforces, etc. - and focusing on value-adding activities only. Maintaining a continuous flow of work on site, contractors can make use of different tools (such as plan-do-check-act) where everything is documented and responsibility is taken for each and every action. Contractors can identify possible sources of waste when they do their risk assessment on site. The sixth step will be to share with other workmates on site the waste likely to be encountered, and how to reduce this waste so that everyone on site is aware of lean construction. This will cultivate continuous learning on the construction site. The seventh step is to seek perfection; this is achieved by repeating steps one to six. It is through repeating these steps that Kaizen (continuous improvement) is achieved.

Table 6: Developed lean construction implementation framework

\begin{tabular}{|c|c|c|c|c|}
\hline Step & Phase & Objective(s) for this step & $\begin{array}{l}\text { Possible tools that } \\
\text { can be used for the } \\
\text { stage }\end{array}$ & References \\
\hline 1. & $\begin{array}{l}\text { Understand current } \\
\text { waste reduction } \\
\text { practices at the } \\
\text { targeted construction } \\
\text { site }\end{array}$ & $\begin{array}{l}\text { - To assess and determine the } \\
\text { level of awareness of construction } \\
\text { waste among contractors on site }\end{array}$ & $\begin{array}{l}\text { Questionnaires, } \\
\text { daily huddle } \\
\text { meetings }\end{array}$ & \\
\hline 2. & $\begin{array}{l}\text { Educate all contractors } \\
\text { taking part in the } \\
\text { project about lean } \\
\text { construction and its } \\
\text { benefits }\end{array}$ & $\begin{array}{l}\text { - To ensure that top management } \\
\text { and everyone else understands } \\
\text { lean principles and is on-board } \\
\text { for successful implementation of } \\
\text { lean. }\end{array}$ & $\begin{array}{l}\text { Daily huddle } \\
\text { meetings } \\
\text { Toolbox talks }\end{array}$ & $\begin{array}{l}{[16][17][18]} \\
{[58]}\end{array}$ \\
\hline 3 & Specify value & $\begin{array}{l}\text { - To outline value from the } \\
\text { project viewpoint and from the } \\
\text { customer's own definition and } \\
\text { needs }\end{array}$ & $\begin{array}{l}\text { Value analysis } \\
\text { mapping } \\
\text { Process analysis }\end{array}$ & $\begin{array}{l}{[49][45][21]} \\
{[23]}\end{array}$ \\
\hline 4 & Identify value stream & $\begin{array}{l}\text { - To identify the activities that } \\
\text { deliver customer value } \\
\text { - To distinguish between value- } \\
\text { adding activities, essential non- } \\
\text { value-adding activities, and non- } \\
\text { essential value-adding activities } \\
\text { - To identify actual and potential } \\
\text { sources of waste }\end{array}$ & $\begin{array}{l}\text { Process mapping } \\
\text { Value stream } \\
\text { mapping } \\
\text { Process flow chart } \\
5 \text { Whys }\end{array}$ & $\begin{array}{l}{[10][19][20]} \\
{[22][59]}\end{array}$ \\
\hline 5 & $\begin{array}{l}\text { Establish flow of } \\
\text { products }\end{array}$ & $\begin{array}{l}\text { - To create a continuous flow of } \\
\text { work by revising Gantt chart } \\
\text { where necessary } \\
\text { - To standardise }\end{array}$ & $\begin{array}{l}\text { Poka-yoke } \\
5 \text { S process } \\
\text { Visual controls } \\
\text { 5Whys } \\
\text { Plan-do-check-act } \\
\text { Last planner system }\end{array}$ & $\begin{array}{l}\text { [7] [13] [16] } \\
{[26][27]}\end{array}$ \\
\hline 6 & Pull production & $\begin{array}{l}\text { - To produce exactly what the } \\
\text { customer wants at the exact time } \\
\text { given by the customer } \\
\text { - To be guided by drawings } \\
\text { received from the customer }\end{array}$ & $\begin{array}{l}\text { JIT } \\
\text { Kanban system }\end{array}$ & $\begin{array}{l}{[66][69][70]} \\
{[71]}\end{array}$ \\
\hline 7 & Seek perfection & $\begin{array}{l}\text { - To provide a perfect solution } \\
\text { without defects or mistakes, and } \\
\text { do continuous improvements } \\
\text { - To have close communication } \\
\text { with the customer }\end{array}$ & Kaizen & $\begin{array}{l}{[70][72][73]} \\
{[75]}\end{array}$ \\
\hline
\end{tabular}

\section{EVALUATING THE FRAMEWORK}

\subsection{Case description}

This framework was evaluated using a project for the refurbishment of government offices in South Africa. One of the authors had participated in this project. The scope of the project was as follows:

- Demolition of some walls to extend offices

- Renovation and replacement of the roof 
- Mechanical engineering services: Installation of new air conditioning units, installation of new fire fighting equipment, and new plumbing pipes.

- Electrical engineering services: Installation of new lighting inside and outside the building, upgrading of the existing distribution board, installation of access control, installation of new small power, and installation of a generator and an automatic transfer switch linked to the generator

- Installation of new ceiling

- Internal plastering and internal painting

- $\quad$ External paving

- Construction of a covered outdoor waiting area.

\subsection{Understanding current waste reduction practices at the targeted construction site}

Semi-structured interviews were conducted to determine the level of understanding of lean construction from the site foremen, site manager, and project manager. Each interviewee was briefed about lean thinking and different waste types based on the work of Liker \& Meier [51] and Womack \& Jones [74]. During the interviews, these team leaders were requested to provide waste examples from their experience.

\subsection{Educating all contractors taking part in the project about lean construction and its benefits}

The author made a presentation on lean construction and its benefits to all contractors on-site during the daily toolbox talks. The objective was to ensure that everyone on site understands lean construction principles and is on board for successful implementation of lean.

\subsection{Specify value}

'Value' stands for what the customer agrees to pay in return. The value in this construction project was to achieve heating, cooling, fresh air supply, ventilation, fire detection systems, fire protection systems, lighting, and power supply.

\subsection{Identify value stream}

A Gantt chart was used to help identify the value stream. Activities on the Gantt chart were shared on noticeboards on-site so that everyone had a chance to appreciate the value stream. The importance of finishing the project on time and of religiously following the Gantt chart was emphasised to everyone. Identification of sources of waste and of potential sources of waste was done on-site. Demonstration of value-adding, non-value-adding, and unnecessary activities for each construction process was done. Value-adding activities were defined as those activities that directly affect the final product of the construction process, increase the economic worth of the process, and are valued by the customer.

\subsection{Establish flow of products}

A continuous flow of work was created by revising the Gantt chart when necessary. Waste in construction is assumed to be physical - for example, waste of materials in the construction process - but in reality there are multiple activities that do not add any value and should be regarded as waste in this industry. The flow of products was defined as the movement of materials, information, and equipment through a system. This step is necessary, as it enhances the flow of materials and information in a construction process.

\subsection{Pull production}

Pull production aims to ensure just-in-time coordination between upstream and downstream tasks. The author was on site twice a week to ensure that everything was delivered just in time to avoid any delays. Materials and information were delivered to the next station at the right time, at the right place, and without delay or unnecessary storage. Architectural drawings and design drawings were delivered in time by the designing team to the contractor. The Kanban system was also used to achieve pull production. This helps in controlling and balancing the resources required in order to achieve project completion.

\subsection{Seeking perfection}

Continuous improvement (Kaizen) was done to provide a perfect solution without mistakes. The project deadline should be met, and the client's needs satisfied, saving on project costs and reducing project duration. 


\subsection{Improved lean implementation framework}

The improved lean implementation framework is developed after the evaluation phase. This framework can be used in lean construction for electrical and mechanical engineering services.

Table 7: Improved lean construction implementation framework

\begin{tabular}{|l|l|l|l|}
\hline Step & Phase & $\begin{array}{l}\text { Lean tools to be } \\
\text { used }\end{array}$ & Responsible people \\
\hline 1 & $\begin{array}{l}\text { Understand current waste reduction } \\
\text { practices at the targeted } \\
\text { construction site }\end{array}$ & $\begin{array}{l}\text { Semi-structured } \\
\text { interviews }\end{array}$ & $\begin{array}{l}\text { Site foreman, site manager, } \\
\text { project manager }\end{array}$ \\
\hline 2 & $\begin{array}{l}\text { Educate contractors about lean } \\
\text { benefits, and focus on mind-set } \\
\text { change }\end{array}$ & $\begin{array}{l}\text { Toolbox talk and } \\
\text { daily huddle } \\
\text { meeting }\end{array}$ & $\begin{array}{l}\text { Construction team (employees) on } \\
\text { site }\end{array}$ \\
\hline 3 & $\begin{array}{l}\text { a) Specify value (electrical } \\
\text { engineering) }\end{array}$ & $\begin{array}{l}\text { Value analysis } \\
\text { mapping }\end{array}$ & $\begin{array}{l}\text { Technicians, site foremen } \\
\text { (mechanical \& electrical), site } \\
\text { manager, project manager }\end{array}$ \\
\hline 4 & $\begin{array}{l}\text { Identify value stream } \\
\text { engineering) }\end{array}$ & $\begin{array}{l}\text { Process flow chart } \\
\text { Gantt chart }\end{array}$ & $\begin{array}{l}\text { Site foreman, site manager, } \\
\text { project manager }\end{array}$ \\
\hline 5 & Establish work flow & $\begin{array}{l}5 \text { whys for waste } \\
\text { elimination }\end{array}$ & $\begin{array}{l}\text { Site foreman, site manager, } \\
\text { project manager }\end{array}$ \\
\hline 6 & Pull production & Kanban & $\begin{array}{l}\text { Project manager, architects, } \\
\text { quantity surveyor, engineers }\end{array}$ \\
\hline 7 & Seek perfection & Kaizen & \\
\hline
\end{tabular}

\section{CONCLUSION}

In this paper, a lean implementation framework has been developed and evaluated in the context of electrical and mechanical engineering services in the construction industry in South Africa. The benefits of adopting lean construction as highlighted in the paper are immense, and will make the industry more resource-efficient. From the systematic literature review done, it was evident that lean construction techniques have not been practised and implemented in the mechanical (HVAC) and electrical construction services. The study contributes to covering that gap by developing a lean construction framework. The next step in this study is to implement this framework fully, and further resynthesize and improve the framework. The authors also seek to refine the implementation of the high level tools of lean construction, such as JIT, in a project setting.

\section{REFERENCES}

[1] Abbasian-Hosseini, S.A., Nikakhtar, A. \& Ghoddousi, P. 2014. Verification of lean construction benefits through simulation modeling: A case study of bricklaying process. KSCE Journal of Civil Engineering, 18(5), pp. 1248-1260.

[2] Abdelhamid, T. \& Salem, S. 2005. Lean construction: A new paradigm for managing construction projects. In: Proceedings of the International Workshop on Innovations in Materials and Design of Civil Infrastructure, Cairo Egypt, 28-29 December 2005, pp. 28-29.

[3] Adamu, I. \& Howell, G. 2012. Applying last planner in the Nigerian construction industry. Twentieth Annual Conference of the International Group for Lean Construction (IGLC-20), San Diego, CA, July 2005, pp. 18-22.

[4] Adamu, S. \& Hamid, R.A. 2012. Lean construction techniques: Implementation In Nigeria construction industry. Canadian Journal on Environmental, Construction and Civil Engineering, 3(4), pp. 186-193.

[5] Ahiakwo, O., Oloke, D., Suresh, S. \& Khatib, J. 2013. A case study of last planner system implementation in Nigeria. 21st Annual Conference of the International Group for Lean Construction, IGLC, Fortaleza, Brazil, 2013, pp. 699-707.

[6] Ahmed, S. \& Forbes, L. 2011. Modern construction: Lean project delivery and integrated practices. New York: CRC Press.

[7] Akinradewo, O., Oke, A., Aigbavboa, C. \& Ndalamba, M. 2018. Benefits of adopting lean construction technique in the South African construction industry. International Conference on Industrial Engineering and Operations Management, November 2018, pp. 1271-1277.

[8] Alarcon, L. 1997. Tools for the identification and reduction of waste in construction projects. Lean construction. $3^{\text {rd }}$ edition. CRC Press Rotterdam, pp 374-383.

[9] Al-Aomar, R. 2012. Analysis of lean construction practices at Abu Dhabi construction industry. Lean Construction Journal, 2012, pp. 105-121. 
[10] Alves, T. da C.L., Pestana, A.C.V.M.F., Gilbert, E. \& Hamzeh, F. 2016. Lean principles for the management of construction submittals and RFIs. Journal of Professional Issues in Engineering Education and Practice, 142(4), pp 46-70.

[11] Ansah, R.H. \& Sorooshian, S. 2017. Effect of lean tools to control external environment risks of construction projects. Sustainable Cities and Society, 32, pp. 348-356.

[12] Arbulu, R. 2002. Improving construction supply chain performance: Case study on pipe supports used in power plants. Master's of Engineering thesis, Construction Engineering and Management Program. Berkeley: University of California.

[13] Arbulu, R., Ballard, G. \& Harper, N. 2003. Kanban in construction. In: Proceedings of IGLC-11, Virginia Tech, Blacksburgh, Virginia, USA, pp. 16-17.

[14] Arleroth, J. \& Kristensson, H. 2011. Waste in lean construction: A case study of a PEAB construction site and the development of a lean construction tool. Master of Science Thesis in the Master of Supply Chain Management. Department of Technology Management and Economics, Chalmers University of Technology Gothenburg, Sweden.

[15] Aziz, R.F. \& Abdel-Hakam, A.A. 2016. Exploring delay causes of road construction projects in Egypt. Alexandria Engineering Journal, 55(2), pp. 1515-1539.

[16] Aziz, R.F. \& Hafez, S.M. 2013. Applying lean thinking in construction and performance improvement. Alexandria Engineering Journal, 52(4), pp. 679-695.

[17] Babalola, O., Ibem, E.O. \& Ezema, I.C. 2019. Implementation of lean practices in the construction industry: A systematic review. Building and Environment, 148(May 2018), pp. 34-43. https://doi.org/10.1016/j.buildenv.2018.10.051

[18] Bajjou, M.S., Chafi, A. \& En-Nadi, A. 2017a. A comparative study between lean construction and the traditional production system. International Journal of Engineering Research in Africa, 29, pp. 118-132.

[19] Bajjou, M.S., Chafi, A., En-Nadi, A. \& El Hammoumi, M. 2017b. The practical relationships between lean construction tools and sustainable development: A literature review. Journal of Engineering Science and Technology Review, 10(4), pp. 170-177.

[20] Bajjou, M.S., Chafi, A. \& En-Nadi, A. 2017c. The potential effectiveness of lean construction tools in promoting safety on construction sites. International Journal of Engineering Research in Africa, 33, pp. 179-193.

[21] Bajjou, M.S. \& Chafi, A. 2018. Lean construction implementation in the Moroccan construction industry: Awareness, benefits and barriers. Journal of Engineering, Design and Technology, 16(4), pp. 533-556.

[22] Ballard, G. \& Howell, G. 1994. Implementing lean construction: Stabilizing work flow. Lean construction. $2^{\text {nd }}$ edition. CRC Press Rotterdam, pp. 105-114.

[23] Ballard, G. \& Howell, G. 2003. Lean project management. Building Research \& Information, 31(2), pp. 119-133.

[24] Barlow, J. 1996. Partnering, lean production and the high performance workplace. In: 4th Annual Conference of the International Group for Lean Construction. Birmingham, UK, pp. 24-37

[25] Bearman, M. \& Dawson, P. 2013. Qualitative synthesis and systematic review in health professions education. Medical Education, 47(3), pp. 252-260.

[26] Bicheno, J. \& Holweg, M. 2016. The lean toolbox: The handbook for lean transformation. $5^{\text {th }}$ Edition, Production and Inventory Control, Systems and Industrial Engineering (PICSIE) Books, Buckingham, England

[27] Caldera, H.T.S., Desha, C. \& Dawes, L. 2018. Exploring the role of lean thinking in sustainable business practice: A systematic literature review. Journal of Cleaner Production, 167, pp. 1546-1565.

[28] Du Plessis, C (ed.) 2002. Agenda 21 for Sustainable Construction in Developing Countries, a discussion document. WSSD edition, CSIR Building and Construction Technology, Pretoria, South Africa, Boutek report No Bou E, 204(6).

[29] Carneiro, S., Campos, I., Oliveira, D.D. \& Neto, J. 2012. Lean and green: A relationship matrix. In: Proceedings of the 20th Annual Conference of IGLC, San Diego ,USA.18-20 July 2012,pp. 120-130

[30] Conner, G. 2009. Lean manufacturing for the small shop. Dearborn: Society of Manufacturing Engineers.

[31] Dakhli, Z., Lafhaj, Z. \& Benrard, M. 2016. Application of lean to the bidding phase in building construction: A French contractor's experience. International Journal of Lean Six Sigma, 8(2), pp. 153-180.

[32] Dondofema, R.A., Matope, S. \& Akdogan, G. 2017. Lean applications: A survey of publications with respect to South African industry. South African Journal of Industrial Engineering, 28(1), pp. 103-113.

[33] Egan, J. 1998. Rethinking construction. (The report of the construction task force). London: Department of Environment, Transport and Regions.

[34] El-Kourd, R. 2009. A study of lean construction practices in Gaza Strip. Master's thesis. Gaza: Civil Engineering Department, Islamic University of Gaza, p. 121.

[35] Emuze, F. \& Smallwood, J. 2013. The integration of health and safety (H\&S), lean and sustainability in construction: A literature review. In Proceedings IGLC-21, July 2013, Fortaleza, Brazil, pp. 853-862.

[36] Erol, H., Dikmen, I. \& Birgonul, M.T. 2017. Measuring the impact of lean construction practices on project duration and variability: A simulation-based study on residential buildings. Journal of Civil Engineering and Management, 23(2), pp. 241-251. 
[37] Ferng, J. \& Price, A. 2005. An exploration of the synergies between six sigma, total quality management, lean construction and sustainable construction. International Journal of Six Sigma and Competitive Advantage, 1(2), pp. 167-187.

[38] Fitchett, A. \& Hartmann, D. 2017. The application of lean design to space planning and construction. Transactions of the Royal Society of South Africa, 72(3), 3 July 2017, pp. 255-265.

[39] Green, S. 2005. Systematic review and meta-analysis. Singap. Med. J., 46(6), pp. 270-274.

[40] Hosseini, S., Nikakhtar, A., Wong, K. \& Zavichi, A. 2011. Implementing lean construction theory into construction processes' waste management. International Conference on Sustainable Design and Construction, Kansas City, Missouri, March 23-25,2011,pp. 414-420

[41] Ikuma, L.H., Nahmens, I. \& James, J. 2010. Use of safety and lean integrated kaizen to improve performance in modular homebuilding. Journal of Construction Engineering and Management, 137(7), pp. 551-560.

[42] Issa, U.H. 2013. Implementation of lean construction techniques for minimizing the risks effect on project construction time. Alexandria Engineering Journal, 52(4), pp. 697-704.

[43] Khanh, H.D. \& Kim, S.Y. 2015. Development of waste occurrence level indicator in Vietnam construction industry. Engineering, Construction and Architectural Management, 22(6), pp. 715-731.

[44] Koksal, G. \& Egitman, A. 1998. Planning and design of industrial engineering education quality. Computers \& Industrial Engineering, 35(3-4), pp. 639-642.

[45] Howell, G. (1999). What is lean construction? Proceedings of the 7th Conference of the International Group for Lean Construction, Berkeley, California, USA ,26-28 ${ }^{\text {th }}$ July 1999,pp.1-10

[46] Koskela, L. 1992. Application of the new production philosophy to construction. CIFE, Technical Report No. 72. Stanford: Stanford University, p. 75.

[47] Koskela, L. 1994. Lean construction. Kensington: N.S.W. Institution of Engineers Australia.

[48] Koskela, L. \& Howell, G. 2000. Reforming project management: The role of lean construction. Proceedings of 8th Conference of International Group for Lean Construction, Brighton, Brazil, 17-19 ${ }^{\text {th }}$ of July 2000 ,pp. 30-39.

[49] Koskela, L., Huovila, P. \& Leinonen, J. 2002. Design management in building construction: From theory to practice. Journal of Construction Research, 3(1), pp. 1-16.

[50] Lehman, T. \& Reiser, P. 2000. Maximizing value \& minimizing waste: Value engineering and lean construction. New York: Lean Construction Institute.

[51] Liker, J.K. \& Meier, D. 2004. The Toyota way. $2^{\text {nd }}$ ed., New York: McGraw Hill.

[52] Love, P., Zahir, I. \& David, E. 2003. Learning to reduce rework in projects: Analysis of firm's organizational learning and quality practices. Project Management Journal, 1(September), pp. 13-25.

[53] Mandujano, M.G., Alarcon, L.F., Kunz, J. \& Mourgues, C. 2016. Identifying waste in virtual design and construction practice from a lean thinking perspective: A meta-analysis of the literature. Journal of Construction, 15(3), pp. 107-118.

[54] Marhani, M.A., Jaapar, A., Bari, N.A.A. \& Zawawi, M. 2013. Sustainability through lean construction approach: A literature review. Procedia - Social and Behavioural Sciences, 101, pp. 90-99.

[55] Marosszeky, M., Thomas, R., Karim, K., Davis, S. \& McGeorge, D. 2002. Quality management tools for lean production: Moving from enforcement to empowerment. In: Proceedings, IGLC-10, 10th Conference of International Group for Lean Construction, Gramado, Brazil , 6-8 ${ }^{\text {th }}$ August 2002, pp. 87-99.

[56] Miron, L.I.G., Kaushik, A. \& Koskela, L. 2015. Target value design: The challenge of value generation. In: 23rd Annual Conference of the International Group for Lean Construction, Perth, Australia, July 29-31,pp. 815-825

[57] Nahmens, I. \& Ikuma, L.H. 2009. An empirical examination of the relationship between lean construction and safety in the industrialised housing industry. Lean Construction Journal, 1(June), pp. 1-12.

[58] Nahmens, I. \& Ikuma, L.H. 2012. Effects of lean construction on sustainability of modular homebuilding. Journal of Architectural Engineering, 18(2), pp. 155-163.

[59] Nielsen, Y. \& Tezel, A. 2013. Lean construction conformance among construction contractors in Turkey. Journal of Management in Engineering, 29(3), pp. 236-250.

[60] Ogunbiyi, O.E. 2014. Implementation of the lean approach in sustainable construction: A conceptual framework. PhD thesis. Preston: University of Central Lancashire.

[61] Paez, O., Solomon, J., Salem, S. \& Genaidy, A. 2005. Moving from lean manufacturing to lean construction: Toward a common sociotechnological framework. Wiley Periodicals, Human Factors and Ergonomics, Manufacturing Journal, 15(2), pp. 233-245.

[62] Picchi, F.A. \& Granja, A.D. 2004. Construction sites: Using lean principles to seek broader implementations. In: Proceedings of the 12th Annual Conference of the International Group for Lean Construction (IGLC-12), Helsingor,Denmark,3-5 ${ }^{\text {th }}$ August 2004 ,pp.529-541.

[63] Takim, R. \& Akintoye, A. 2002. Performance indicators for successful construction project performance. In: 18th Annual ARCOM Conference, 2, pp. 545-555.

[64] Tezel, A., Koskela, L. \& Aziz, Z. 2018. Lean thinking in the highways construction sector: Motivation, implementation and barriers. Production Planning \& Control, 29(3), pp. 247-269.

[65] Alves, T. da C.L.A., Milberg, C. \& Walsh, K.D. 2012. Exploring lean construction practice, research, and education. Engineering, Construction and Architectural Management, 19(5), pp. 512-525. 
[66] Tommelein, I.D. 2015. Journey toward lean construction: Pursuing a paradigm shift in the AEC industry. Journal of Construction Engineering and Management, 141(6), pp.926-948. https: / /doi.org/10.1061/(asce)co.1943-7862.0000926

[67] Saieg, P., Sotelino, E.D., Nascimento, D. \& Caiado, R.G.G. 2018. Interactions of building information modeling, lean and sustainability on the architectural, engineering and construction industry: A systematic review. J. Clean. Prod., 174, pp. 788-806.

[68] Salem, O. \& Zimmer, E. 2005. Application of lean manufacturing principles to construction. Lean Construction Journal, 2(October), pp. 51-54.

[69] Salem, O., Solomon, J., Genaidy, A. \& Minkarah, I. 2006. Lean construction: From theory to implementation. Journal of Management in Engineering, 22(4), pp. 168-175.

[70] Sarhan, J.G., Xia, B., Fawzia, S. \& Karim, A. 2017. Lean construction implementation in the Saudi Arabian construction industry. Construction Economics and Building, 17(1), pp. 46-69.

[71] Shang, G. \& Sui Pheng, L. 2014. Barriers to lean implementation in the construction industry in China. Journal of Technology Management in China, 9(2), pp. 155-173.

[72] Umstot, D. 2013. Introduction to lean construction: What is lean construction and how can it benefit you? [Webinar] London: ABC Webinar.

[73] Watson, M. 2003. Lean-examples in construction, A report of workshop organized by the Construction Productivity Network on the 23rd Sept 2003 at The Orange Studio. Caxton House, Cannon Street, Birmingham.

[74] Womack, J. \& Jones, D. 1996. Lean thinking. New York: Simon \& Schuster.

[75] Yu, H., Tweed, T., Al-Hussein, M. \& Nasseri, R. 2009. Development of lean model for house construction using value stream mapping. Journal of Construction Engineering and Management, 135(8), pp. 782-790.

[76] Zhang, L., Chen, X. \& Suo, Y. 2017. Interrelationships among critical factors of work flow reliability in lean construction. Journal of Civil Engineering and Management, 23(5), pp. 621-632.

[77] Emuze, F.A. \& Smallwood, J.J. 2011. Clients' perceptions of non-value adding activities in South Africa. In: Proceedings of the 19th Conference of the International Group for Lean Construction (IGLC), 13-15 July, Lima, Peru, pp. 668- 677.

[78] Construction Industry Development Board. 2004. SA construction industry status report - 2004: Synthesis review on the South African construction industry and its development. Pretoria: CIDB.

[79] Othman, A.A.E. 2011. Lean principles as a strategic option for delivering innovative sustainable construction projects: A client value driven approach. In: Proceedings of the 6th Built Environment Conference of the Association of Schools of Construction of Southern Africa (ASOCSA), 31 July-2 August, Johannesburg, South Africa, pp. 174-184.

[80] Emuze, F. \& Ungerer, H. 2014. Change in South Africa construction: Lessons from lean thinking. 22nd Annual Conference of the International Group for Lean Construction: Understanding and Improving Project Based Production, IGLC 2014, (051), pp. 1121-1131.

[81] Monyane, T., Awuzie, B. \& Emuze, F. 2017. Performance indicators for lean construction in South Africa: Lessons from the Port Elizabeth province. In Proceedings of the $4^{\text {th }}$ International Conference on Infrastructure Development and Investment Strategies for Africa ,Livingstone, Zambia, 30August -1 September, pp. 147-156. 